\title{
Teaching Methods and Acquisition of Social Skills among Primary Schools Pupils in IkotEkpene Local Government Area
}

\author{
Nwachukwu Kingsley Ezechinyere ${ }^{1 *}$, NdifrekeOkon Jonah ${ }^{2}$, Okoro, Uloaku Nene ${ }^{3}$ \\ ${ }^{\mathrm{T}}$ (Ph.D), Department of Early Childhood and Special Education, Faculty of Education, University of Uyo, Ikpa Rd, Uyo, \\ Nigeria \\ ${ }^{2}$ Department of Early Childhood and Special Education, Faculty of Education, University of Uyo, Uyo, AkwaIbom State, \\ Nigeria \\ ${ }^{3}$ (Ph.D), Department of Special Needs Education, Alvan Ikoku Federal Collage of Education Owerri, Orlu Rd, Owerri, \\ Nigeria
}

\section{*Corresponding Author}

Nwachukwu Kingsley Ezechinyere

\author{
Article History \\ Received: 09.01.2021 \\ Accepted: 20.01.2021 \\ Published: 30.01 .2021
}

\begin{abstract}
This study investigated the Teaching methods and acquisition of social skills among primary school pupils in IkotEkpene Local Government Area. Quasi-experimental research design was employed for this study. Population of the study was 2,903 primary one pupils in39 public primary schools. 218 pupils was the sample size selected through multistage sampling technique. The instrument for data collection was modified Pupil's Social Skills Acquisition Rating Scale (PSSARS).The instrument was validity determined by experts. Cronbach's Alpha was used to determine the internal consistency of Pupil's Social Skills Acquisition Rating Scale (PSSARS) which yielded coefficient indices of 0.73. Mean analysis and standard deviation were used to answer the research questions while analysis of covariance (ANCOVA) was used to test the hypotheses. The study revealed that drama and play-way methods of teaching enhance acquisition of pupil's social skills better than the conventional method of teaching. This showed that participatory learning in form of drama, role play, songs etc. stimulates interests and enhances pupil's motivation to interact which leads to development of their social skills. Pupils understand concepts and have higher retention when they actively participate in the lesson. It was also concluded from the findings of this study, that pupils will develop proper social skills like friendliness skill, communication skill cooperative skill among others that will make socializing in the society and at large while. Based on the findings of the study, the researcher recommended among others that primary school teachers should adopt drama and play way methods of teaching as effective methods for teaching primary school pupils. Curriculum planners should inculcate drama and play-way methods of teaching in the teaching and learning in primary schools.
\end{abstract}

Keywords: Teaching Methods, Drama, Play and Social Skills.

\section{INTRODUCTION}

Education is defined as the wise, hopeful and respectful cultivation of learning undertaken in the belief that all should have the chance to share in life. Education is an indispensable tool in nations building. It is a process of systematic training and instruction designed to transmit knowledge and acquisition of skills, potentials and abilities which will enable an individuals to contribute efficiently to the growth and development of his society and nations. It involves all around development of an individually physically, socially, morally, intellectually and mentally [1]. Education of an individual is in stages, the first and very important stage is the early childhood stage.

Early childhood is a time of bridge building. It is a time in a child's life when bridges are built between the shelter of home and the demands of the school; between play with a few neighbourhood friends and relationship with many children. It is that period of human development which falls between births to eight years (birth- 8 years). The time

Copyright (C) 2021 The Author(s): This is an open-access article distributed under the terms of the Creative Commons Attribution 4.0 International License (CC BY-NC 4.0) which permits unrestricted use, distribution, and reproduction in any medium for noncommercial use provided the original author and source are credited. 
from birth to eight years is a critical period in the development of many foundational skills in all areas of development. This is the time when environmental enrichment or deprivation makes its greatest impact. Since development is proceeding at a very fast rate, unfavourable experiences such as lack of adequate food, health care, nurturance or stimulation, unhealthy living conditions and exploitative working conditions hinder development to a considerable extent. In the same way, favourable conditions foster development. The effect is long-lasting since the foundation of development in later years is laid at this age. It must be appreciated that development is not simply the result of mechanical acts of feeding and physical care, but rather of a feeling of total well-being that arises from growing up in a healthy atmosphere with love, warmth and opportunities for learning. Psychologists and educationists recognize this fact and made early childhood education an important subject of study since the rest of education system is built upon it. Any defect or impairment at this stage could go a long way in affecting the later intellectual ability and adjustment of the child [2].

Social skills are critical to successful functioning in life. These skills enable individuals to know what to say, to make good choices, and how to behave appropriately in different situations. Social skills are components of behaviour that help an individual understand and adapt across a variety of social settings. Children's social skills are constantly developing at different ages and stages. Skills build upon earlier skills, are often inter-related and affect other areas of development such as language, thinking, planning and decision making. Children's development of social skills is also dependent upon development in these other areas associated brain growth. Babies and toddlers engage in more concrete thinking based on what they can see. Preschoolers begin to have more conscious control and use abstract thinking, such as understanding of the past and the future to guide their thoughts, feelings and actions. However, it is useful to remember that these skills are just beginning in preschoolers and that they may find it difficult to make responsible decisions and 'do the right thing' on their own.

The term "social skills" is generic and refers to a very heterogeneous set of interpersonal behaviours. Simply stated, social skills are specific, identifiable skills that result in socially competent behaviour [3] and effective social interactions with other people [4]. Many definitions describe social skills in terms of an interaction between the individual and his/her environment. For example, Argyris [5] views social skills as those behaviors that enhance a person's ability to contribute to the larger social network to which he/she belongs. Within these networks, such skills not only enable an individual to adjust and respond appropriately to environmental cues but can also provide the person with a means of coping in stress-inducing situations as well as avoiding interpersonal conflict [6].

The development of social skills lays a critical foundation for later academic achievement as well as workrelated skills [7]. Social development is such a key issue with young children that a number of teaching methods such as drama and play-way and so on to address social skills have been advocated. Some of the causes of deficit in social skills in the world, Nigeria and specifically IkotEkpene Local Government Area include inability to set up classrooms to enhance social development, providing play opportunities to promote social functioning, and teaching social skills directly.

To Argyris [5], the following examples represent some of the fundamental principles of relating well to others.

Friendliness refers to the ability to put up a warm personality that makes you approachable, easy to relate with and without any hostility. Aside from being warm and devoid of hostility, a friendly person is someone who has a great level of respect for others. To be friendly is being able to show patience and care as well as spending time with people. Friendliness is a skill that is of great importance in the life of an individual especially children. It reduces fight and strife. Friendly people are good to be around, they are sociable, pleasant companions who always knows how to say things the right way. There are natural facilitators in groups, making the social round move more smoothly.

Cooperative skill is an essential part of workplace success. Like a basketball team working together to set up the perfect shot, every team member has a specific role to play in accomplishing tasks on the job. Although it may seem as if one player scored the basket, that basket was made possible by many people's planning, coordination, and cooperation to get that player the ball. Employers look for people who not only know how to work well with others, but who understand that not every player on the team can or will be the one who gets the ball. When everyone in the workplace works together to accomplish goals, everyone achieves more. The ability to work as part of a team is of the most important skills in today's job market. Employers are looking for workers who can contribute their own ideas, but also want people who can work with others to create and develop projects and plans. Cooperative skill involves building relationships and working with other people using a number of important skills and habits:

i. Working cooperatively

ii. Contributing to groups with ideas, suggestions, and effort

iii. Communication (both giving and receiving)

iv. Sense of responsibility 
v. Healthy respect for different opinions, customs, and individual preferences

vi. Ability to participate in group decision-making

Cooperative skill promotes individual and team success through group interaction. They are fun to play and include all pupils, regardless of age, size, or ability level. Games programmes offer enjoyable ways to learn many life skills. Some of the most important skills to be learned are the value of participation, the joy of effort, cooperation, communication, sharing, and teamwork. Cooperative games and activities provide unique opportunities for pupils to learn many of these skills through positive interaction, as well as to learn to communicate effectively and to develop an appreciation of fair play. In addition, teachers have the opportunity to ensure that their programme is fun and inclusive regardless of age, size, or ability level. Too often children are put into the win/lose situation where it becomes easy to lose sight of the value that the activity has to offer, and especially the joy of participation. The four basic components of cooperative skills includes, cooperation, acceptance, involvement and fun.

Communication skills are important to everyone - they are how we give and receive information and convey our ideas and opinions with those around us. Communication comes in many forms:

i. Verbal (sounds, language, and tone of voice)

ii. Aural (listening and hearing)

iii. Non-verbal (facial expressions, body language, and posture)

iv. Written (journals, emails, blogs, and text messages)

v. Visual (signs, symbols, and pictures)

It is important to develop a variety of skills for both communicating to others and learning how to interpret the information received from others. Knowing our audience and understanding how they need to receive information is equally important as knowing ourselves. Communication skills are necessary for the development of self-advocacy and self-determination, important skills for lifelong success.

The success of teaching is determined by effective and efficient teaching process. An effective and efficient teaching can only be actualized based on the teacher's knowledgeability of the subject and the use of appropriate $\operatorname{method}(\mathrm{s})$ in the teaching -learning process. Teaching methods as what method technique or approach, an individual or group of teachers choose and use in actual classroom situation. Some methods of teaching employed by teachers in the early childhood education are viz: play way method, supervised activity method, demonstration, excursion method, assignment method, pictorial method, storytelling method, drama method [8]. Methods that may be useful in this regard are drama method and play-way method of instruction. This is because there involve active participation of the learner in the teaching and learning process. These methods may also arouse the interest of learners. Although the use of drama method and play-way method of instructions have been tried in the teaching of Christian Religious Studies, English Language, and Mathematics, and found to be effective.

Drama has been transferred into the field of education through the principles of "being pupil-centred", "activitybased" and self-expressive". Inclusion of drama in education and thus re-creation of topics by integrating them secures permanent learning and encourages pupils to learn The word drama is taken from the Greek word 'dran' which means do or act.

Drama in real life involves action, which is one of the most important methods of seeing life 9]. According to Durusel [10] as cited in Duban and Duzgun [11] drama provides a presentation and interpretation of a physical or mental activity and is a way to transform students' mental and physical potentials into creative acts. According to Littledyke [12], drama as an educational method allows students to reflect, discuss, make connections with real life, and look at the events from different angles. In his own view, Iwuala [13] asserts that topics in all subject areas can be recognized and dramatized by the students in order to make them clear and easier to understand and make learning a pleasurable venture. In other words, the use of drama method of instruction in the teaching of social skills will help in making the pupils develop social skills. Kauts and Monika [14] found that teaching through dramatization was found effective than traditional method with respect to achievement of students in English and gain scores in speaking skills.

Moreover, play is the main factor for mental development of child and is one of the factors influenced on the nurture of forces and talents of child. The main core of children plays forms seeking for his surrounding world and of course in his mind, any experience, even throwing the objects surrounding him is valuable. In types of plays, child shows its imagination and finds an opportunity for indicating his feelings and in all cases dealing with creativeness and experiences the joy of creation. Joyful, movable and attractive plays considerably reduce the stress and even exercise, if conducted by a cheerful style will promote the feeling of progress. 
Children love to play and it is their natural instinct. The play-way method was conceived by Froebel 1837. According to Froebel, play is the work of the children. Play way method of learning is a child centric method where the method of teaching is informal and natural to suit the child's interests. Schools who are using play way method believe that learning is best through play activities. It rejuvenates the children in their leaning. It enhances their learning abilities. Play-way method of teaching give free reign to a child's curiosity and helps a child to grow and bloom. The early work of Popoola [15] reported that there was significant difference in the performance of students in favour of those in guided play group. Aghajani [16] also found that there is significant difference between dependent variables, "social skill" focusing on the group (kindergarten, pre-school and school); and finally by comparing the results of this study with related history in and out of country, it has been concluded that play, play therapy and even type of toy will increase the social skills of children.

A child understands his needs and goals while playing. So play can be an effective way of teaching children. It has been proved that maximum amount of learning results while playing games. While playing games the environment is very relaxed, this makes learning interesting and fun. This is the most desirable method of learning for children. The informal and free atmosphere gives the children a chance to learn concepts and ideas. Play way methods can be incorporated in the school curriculum for teaching languages, mathematics, social skills through a series of activities like songs, free play, gardening, construction activities, mathematical games, checkers, magic squares, puzzles and building blocks Aghajani [16]. It makes teaching and learning a memorable experience for both the learners as well as teachers. Through play way method teaching and learning becomes more lively and interesting. Role plays, projects, theme based learning, field trips, puppetry are a few techniques included in play way method. Play-way method consists of the activities that include a sort of fun or play and give joy to the pupils. The learning is not just limited to cognitive development, but also for the overall development of the child. Aaron [17] who found out that, lessons integrated with role play yielded positive results in that pupils' interest were sustained and also they were able to answer questions posed to them with little or no difficulty. Freitas [18] mentioned that play, by virtue of its social interactive dimension, can develop team-based skills like leadership, coordination and communication skills.

The development of social skills lays a critical foundation for later academic achievement as well as workrelated skills [7]. Social development is such a key issue with young children that a number of methods to address social skills have been advocated. Some of the causes of deficit in social skills in the world, Nigeria and specifically IkotEkpene Local Government Area include inability to set up classrooms to enhance social development, providing play opportunities to promote social functioning, and teaching social skills directly. To Cohen [19], Coie, Dodge and Coppotelli [20], social inability can be a lifelong problem. Therefore it is imperative that social skill deficits be identified early and addressed in much the same way as we identify and address children's learning problems because social incompetence can be more debilitating and detrimental to success in life than learning problems. It is against this background that the researcher is interested investigating the effect of teaching methods (drama method and play-way method) on acquisition of social skills among primary schools pupils in IkotEkpene Local Government Area.

\section{Statement of the Problem}

Nowadays, children tend to exhibit ill behaviours like being impatient, aggressive, disrespectful etc. All these can be as a result of lack of correct social norms and values which may not be properly transmitted in their childhood stage. The family becomes both a training ground for development of social skills and an arena in which those skills are put to use. Social skill deficits can lead to behavioural difficulty in school, low self- esteem, academic failure, concentration difficulties, isolation from peers, and depression. A social skill deficit can also take the form of noncompliance with school procedures, physical or verbal aggression or defiance of authority figures. The lack of social skills can lead to behavioural difficulty in schools, delinquency, and inattentiveness, peers rejection, emotional difficulties, bullying, difficulties in making friends, aggressiveness, problem interpersonal relationships, poor selfconcept, academic failure, concentration difficulties, isolation from peers and oppression.

Looking at the context of school, the relationships formed within this setting and the interactions between them creates a more complete picture of children's development. Studies have shown that children spend most of their time in school thereby making this setting their primary environments. Social skills are an important component of academic achievement, however children from families with low socio-economic status and enrolled in poorly equipped and resourced schools may struggle to succeed academically as they often enter school with fewer social skills, unprepared for the social interactions that facilitate learning and that are crucial to acquire in the early years of schooling. There is therefore the urgent need to devise better and more productive methods of teaching social skills to make it interesting and rewarding to the learners. Its effectiveness, to the best of the researcher's knowledge, is yet to be determined in the teaching of social skills in IkotEkpene Local Government Area. Based on the foregoing, therefore, the problem of this study is to find out the effect of teaching methods (drama method and play-way method) on acquisition of social skills among primary schools pupils in IkotEkpene Local Government Area. 


\section{OBJECTIVE OF THE STUDY}

The main objective of the study was to determine the effect of teaching methods (drama method and play-way method) on acquisition of social skills among primary schools pupils in IkotEkpene Local Government Area. Specifically, the study sought to:

i. To ascertain the difference in pupils' acquisition of friendliness skills when exposed to drama and play-way method.

ii. To determine the difference in pupils' acquisition of cooperative skills when exposed to drama and play-way method.

iii. To find out the difference in pupils' acquisition of communication skills when exposed to drama and play-way method.

\section{Research Questions}

The following research questions are stated to guide the study:

i. What is the difference in pupils' acquisition of friendliness skills when exposed to drama and play-way method?

ii. What is the difference in pupils' acquisition of cooperative skills when exposed to drama and play-way method?

iii. What is the difference in pupils' acquisition of communication skills when exposed to drama and play-way method?

\section{Research Hypotheses}

The following null hypotheses were formulated to guide this study and tested at .05 level of significance:

i. There is no significant difference in pupils' acquisition of friendliness skills when exposed to drama and playway method.

ii. There is no significant difference in pupils' acquisition of cooperative skills when exposed to drama and playway method.

iii. There is no significant difference in pupils' acquisition of communication skills when exposed to drama and play-way method.

\section{RESEARCH METHOD}

This study is a quasi-experimental research design. Specifically, it is a pretest - post-test non-equivalent control group design. This research was carried out in the IkotEkpene Local Government Area of Akwa Ibom State. The population of the study consisted of 2,903 primary three pupils in 39 public primary schools. A sample of 218 primary three pupils from six intact classes was used in the study selected through multi-stage sampling technique. Pupil's Social Skills Acquisition Rating Scale (PSSARS). The instrument has two sections A and B - section A has personal information, instructions and a guide on how pupils were rate themselves, while Section B is segmented into three variables: friendliness, co-operation skill, communication skill, with three/four items each, making a total of 11 items. The items in section B was measured on a 4-point scale of Almost Always =4, Often =3, Sometimes =2 and Almost Never $=1$.The instrument's validity was determined by experts. Cronbach Alpha was used to determine the internal consistency of Pupil's Social Skills Acquisition Rating Scale (PSSARS) which yielded a coefficient indices of0.84, 0.67 and 0.65 respectively. Based on the geographical spread of the population, the researcher trained the teachers who served as research assistants on the use of Drama and play-way methods. Thereafter, Pupil's Social Skills Acquisition Rating Scale (PSSARS) (pretest) was administered to the subjects in the treatment and control group. After administering the pretest to both experimental and control group, the teachers executed treatment programme adhering strictly to the instructional packages prepared for the purpose. Teacher in the control group also taught the control group without drama and play. The classes for subjects in the treatment group and the control group were held during their normal time on the school timetable. Each group lasted for 40 minutes each day, twice a week, for five weeks. Pupil's Social Skills Acquisition Rating Scale (PSSARS) was administered to the subjects in the experimental and control group as post-test after treatment had stopped. Mean and standard deviation were used in answering the research questions. Analysis of Covariance (ANCOVA) was used to test the hypotheses at 0.05 level of significance.

\section{RESULTS}

\section{Research Question One} of teaching?

What is the difference in pupils' acquisition of friendliness skills when exposed to drama and play way methods 
Table-1: Summary of mean and standard deviation of pupils' acquisition of friendliness skill when exposed to drama, play-way and conventional methods of teaching

\begin{tabular}{|l|l|l|l|l|l|l|l|}
\hline Friendliness Skills & \multirow{2}{*}{$\mathbf{N}$} & Pre-test & Post-test & \multirow{2}{*}{ Mean difference(post-test-pre-test) } & Rank \\
\cline { 3 - 7 } & & $\bar{x}$ & SD & $\bar{x}$ & SD & & \\
\hline Drama & 71 & 5.29 & 1.033 & 8.33 & 2.104 & 3.04 & 2 \\
\hline Play-way & 67 & 5.11 & 1.037 & 11.61 & 2.891 & 6.50 & 1 \\
\hline Conventional Method & 80 & 5.12 & 1.047 & 5.61 & 1.496 & 0.49 & 3 \\
\hline
\end{tabular}

The results in Table-1 indicate that the pupil's acquisition of friendless skills mean score is highest when exposed to play-way followed by drama and conventional method lastly with pre-test - post-test mean difference of 6.50,3.04 and 0.49 respectively. This observation shows that pupils taught with drama and play-way method of teaching acquired friendliness skills more than those exposed to conventional method of teaching.

\section{Research Question Two}

What is the difference in pupils' acquisition of co-operative skills when exposed to drama, play-way and conventional method of teaching?

Table-2: Summary of Mean and Standard deviation of pupils acquisition of cooperative skill when exposed to drama, play-way and conventional methods of teaching

\begin{tabular}{|l|l|l|l|l|l|l|l|}
\hline Co-operative Skills & \multirow{2}{*}{$\mathbf{N}$} & \multicolumn{2}{|l|}{ Pre-test } & Post-test & \multirow{2}{*}{ Mean difference(post-test-pre-test) } & \multirow{2}{*}{ Rank } \\
\cline { 3 - 7 } & & $\bar{x}$ & SD & $\bar{x}$ & SD & & \\
\hline Drama & 71 & 4.46 & 0.098 & 10.18 & 1.759 & 5.72 & 1 \\
\hline Play-way & 67 & 4.56 & 1.183 & 8.79 & 2.034 & 4.23 & 2 \\
\hline Conventional Method & 80 & 4.56 & 1.053 & 5.43 & 1.840 & 0.85 & 3 \\
\hline
\end{tabular}

The results in Table-2 indicate that the pupils acquisition of co-operative skills mean score is highest when exposed to drama followed by play-way and lastly conventional methodsof teaching with pre-test - post-test mean difference of 5.72, 4.23 and 0.85 respectively. This observation shows that pupils taught with drama and play-way method of teaching acquired co-operative skills than those exposed to conventional methodof teaching.

\section{Research Question Three}

What is the difference in pupils' acquisition of communication skills when exposed to drama, play-way and conventional methods of teaching?

Table-3: Summary of Mean and Standard deviation of pupils' acquisition of communication skill when exposed to drama, play-way and conventional method of teaching

\begin{tabular}{|l|l|l|l|l|l|l|l|}
\hline Communication Skills & \multirow{2}{*}{$\mathbf{N}$} & Pre-test & Post-test & \multirow{2}{*}{ Mean difference(post-test-pre-test) } & Rank \\
\cline { 3 - 6 } & & $\bar{x}$ & SD & $\bar{x}$ & SD & & \\
\hline Drama & 71 & 5.07 & 1.032 & 11.43 & 2.906 & 6.36 & 1 \\
\hline Play-way & 67 & 5.35 & 1.025 & 8.32 & 2.155 & 2.97 & 2 \\
\hline Conventional Method & 80 & 5.36 & 1.009 & 5.50 & 1.211 & 0.14 & 3 \\
\hline
\end{tabular}

The results in Table-3 indicate that the pupils acquisition of communication skill mean score is highest when exposed to drama followed by play-way and lastly conventional method of teaching with pre-test post-test mean difference of $6.36,2.97$ and 0.14 respectively. This observation shows that pupils taught with drama and play-way acquired communication skills than those exposed to conventional method of teaching.

\section{Testing OF Hypotheses}

\section{Hypothesis One}

There is no significant difference in pupils' acquisition of friendliness skills when exposed to drama, play-way and conventional methods of teaching. 
Table 4: Analysis of Covariance (ANCOVA) of the difference in pupils' acquisition of friendliness skill when exposed to drama, play-way and conventional methods of teaching

\begin{tabular}{|l|l|l|l|l|l|l|}
\hline \multicolumn{1}{|c|}{ Source } & Type III Sum of Squares & df & Mean Square & F & Sig. & Partial Eta Squared \\
\hline Corrected Model & $1318.336^{\text {a }}$ & 3 & 439.445 & 91.049 & .000 & .561 \\
\hline Intercept & 728.248 & 1 & 728.248 & 150.887 & .000 & .414 \\
\hline Pretest & 5.924 & 1 & 5.924 & 1.227 & .269 & .006 \\
\hline Methods & 1312.029 & 2 & 656.015 & 135.921 & .000 & .560 \\
\hline Error & 1032.861 & 214 & 4.826 & & & \\
\hline Total & 17529.000 & 218 & & & & \\
\hline Corrected Total & 2351.197 & 217 & & & \\
\hline a. R Squared $=.561$ (Adjusted R Squared =.555) \\
\hline
\end{tabular}

The result in Table-4 shows that an F-ratio of 135.921 with an associated probability value of 0.000 was obtained with regards to the difference in pupils' acquisition of friendliness skills when exposed to drama, play-way and conventional methods of teaching. Since the associated probability of 0.000 was less than 0.05 , the null hypothesis one which states that there is no significant difference in pupils' acquisition of friendliness skills when exposed to drama, play-way and conventional methods of teaching was rejected. This implies that there is a significant difference in pupils' acquisition of friendliness skills when exposed to drama, play-way and conventional methods of teaching

\section{Hypothesis Two}

There is no significant difference in pupils' acquisition of cooperative skill when exposed to drama, play-way and conventional methods of teaching

Table-5: Analysis of Covariance (ANCOVA) of the difference in pupils' acquisition of cooperative skills when exposed to drama, play-way and conventional methods of teaching

\begin{tabular}{|l|l|l|l|l|l|l|}
\hline Source & Type III Sum of Squares & Df & Mean Square & F & Sig. & $\begin{array}{l}\text { Partial Eta } \\
\text { Squared }\end{array}$ \\
\hline Corrected Model & $907.392^{\mathrm{a}}$ & 3 & 302.464 & 85.667 & .000 & .546 \\
\hline Intercept & 686.470 & 1 & 686.470 & 194.430 & .000 & .476 \\
\hline Pretest & 1.816 & 1 & 1.816 & .514 & .474 & .002 \\
\hline Methods & 907.227 & 2 & 453.614 & 128.478 & .000 & .546 \\
\hline Error & 755.566 & 214 & 3.531 & & & \\
\hline Total & 15663.000 & 218 & & & & \\
\hline Corrected Total & 1662.959 & 217 & & & & \\
\hline a. R Squared = .546 (Adjusted R Squared =.539)
\end{tabular}

\section{Hypothesis Three}

There is no significant difference in pupils' acquisition of communication skills when exposed to drama, playway and conventional methods of teaching.

Table-6: Analysis of Covariance (ANCOVA) of the difference in pupils' acquisition of communication skills when exposed to drama, play-way and conventional methods of teaching

\begin{tabular}{|l|l|l|l|l|l|l|}
\hline Source & $\begin{array}{l}\text { Type III Sum of } \\
\text { Squares }\end{array}$ & df & Mean Square & F & $\begin{array}{l}\text { Sig. } \\
\text { Partial Eta } \\
\text { Squared }\end{array}$ \\
\hline Corrected Model & $1329.411^{\text {a }}$ & 3 & 443.137 & 93.836 & .000 & .568 \\
\hline Intercept & 645.681 & 1 & 645.681 & 136.725 & .000 & .390 \\
\hline Pretest & 3.634 & 1 & 3.634 & .769 & .381 & .004 \\
\hline Methods & 1291.114 & 2 & 645.557 & 136.699 & .000 & .561 \\
\hline Error & 1010.607 & 214 & 4.722 & & & \\
\hline Total & 17368.000 & 218 & & & & \\
\hline Corrected Total & 2340.018 & 217 & & & & \\
\hline a. R Squared $=.568$ (Adjusted R Squared =.562) \\
\hline
\end{tabular}

The result in Table-6 shows that an F-ratio of 136.699 with an associated probability value of 0.000 was obtained with regards to the difference in pupils' acquisition of communication skills when exposed to drama, play-way and conventional methods of teaching. Since the associated probability of 0.000 was less than 0.05 , the null hypothesis one which states that there is no significant difference in pupils' acquisition of communication skills when exposed to drama, play-way and conventional methods of teaching was rejected. This implies that there is a significant difference in pupils' acquisition of communication skills when exposed to drama, play-way and conventional methods of teaching. 


\section{DisCUSSION OF FINDINGS}

The finding with respect to hypothesis one has shown in Table-4 indicates the significant difference in pupils' acquisition of friendliness skills when exposed to drama, play-way and conventional methods of teaching. This means that the null hypothesis one is rejected. Therefore there is a significant difference in pupils' acquisition of friendliness skills when exposed to drama, play-way and conventional methods of teaching. This finding implies that drama and playway brought about cordial relationship among children which in turn enhances friendliness skills. This finding is instrongly corroborated by Kauts and Monika [14] found that teaching through dramatization was found effective than traditional method with respect to achievement of students in English and gain scores in speaking skills. Aghajani [16] also found that there is significant difference between dependent variables, "social skill" focusing on the group (kindergarten, pre-school and school); and finally by comparing the results of this study with related history in and out of country, it has been concluded that play, play therapy and even type of toy will increase the social skills of children.

The finding with respect to hypothesis two has shown in Table-5 indicates the significant difference in pupils' acquisition of cooperative skills when exposed to drama, play-way and conventional methods of teaching. This means that the null hypothesis two is rejected. Therefore there is a significant difference in pupils' acquisition of co-operative skills when exposed to drama, play-way and conventional methods of teaching. This implies that has activities that enhance cooperative skills since it involves more team work than individual work. The findings of this study is in agreement with the early work of Popoola [15] who reported that there was significant difference in the performance of students in favour of those in guidedplay group.

The finding with respect to hypothesis three has shown in Table 6 indicates the significant difference in pupils' acquisition of communication skills when exposed to drama, play-way and conventional methods of teaching. This means that the null hypothesis four is rejected. Therefore there is a significant difference in pupils' acquisition of communication skills when exposed to drama, play-way and conventional methods of teaching. The findings of this study implies that drama and play-way involves more level of interaction with each other than conventional method of teaching that involves more interaction between the individual and the instrument used for the teaching and learning process. This finding supports earlier study of Aaron [17] who found out that lessons integrated with role play yielded positive results in that pupils' interest were sustained and also they were able to answer questions posed to them with little or no difficulty. Freitas [18] mentioned that play, by virtue of its social interactive dimension, can develop teambased skills like leadership, coordination and communication skills.

\section{CONCLUSION}

Drama and play-way methods of teaching enhance acquisition of pupils' social skills better than the conventional method of teaching. The researcher is of the view that our participatory learning in form of drama, role play, play, songs etc. has been thrown away or rather has not been effectively used in most primary schools in IkotEkpene local government area and the utilization of these methods in the teaching and learning of pupils will positively change pupils' level of social skills acquisition. The result showed that there is a significant difference in pupils' acquisition of friendliness, co-operative and communication skills when exposed to drama, play-way and conventional methods of teaching.

\section{RECOMMENDATIONS}

Based on the findings of the study and the conclusions drawn there from, the researcher recommends as follows:

i. The government policies makers, curriculum planners etc. should enforce the use of drama and play-way as recommended in the National Policy of Education.

ii. Private school operators should allow drama and play-way to be used to teaching so as to enable teachers also used them in teaching process.

iii. Teachers and care givers should be trained on how to make these drama and play-way useful in classroom situation. This will enable pupils active participation in the teaching and learning process.

\section{REFERENCES}

1. Osakwe, R. N. (2009). Effect of early childhood education experience on the academic performance of primary school children. Benin City. Osasu Printing Press.

2. Barnett, W. S (2002). Early Childhood Education. In A. Molnar (Ed.), School Reform proposals: The research evidence. Greenwich, CT: Information Age Publishing, Inc.

3. Hops, H. (2003). Children's social competence and skill: Current research practices and future directions. Behavior Therapy, 14, 3-18.

4. Gresham, F. M., \& and Elliott, S. N. (2004).Assessment and classification of children's social skills. A review of methods and issues. School Psychology Review, 13, 292-301. 
5. Argyris, C. (2001). Explorations in interpersonal competence. Journal of Applied Behavioral Science, 1, 58-63.

6. Matson, J. L., Rotatori, A., \& Helsel, W. J. (2004). Development of a rating scale to measure social skills in children: The Matson Evaluation of Social Skills with Youngsters (MESSY). Behavior Research and Therapy, 21, 335-340.

7. McClelland, M. M., \& Morrison, F. J. (2003). The emergence of learning related social skills in preschool children. Early Childhood Research Quarterly, 18(2).

8. Shofoyeke, A. D. (2015). The impact of teaching methods on pre-primary school pupils' learning achievement in protection issues in selected nursery and primary schools in Ondo West Local Government. Journals of Elementary Education, 25 (2), 45-60.

9. Ibitola, A. O. (2009). Essential literature-in-English for senior secondary schools. Ogun: Tonad Publishers Limited.

10. Durusel, G. (2007). Iikogretim Okullari icin uygulamah drama Istanbul: Yuva Yayinlari.

11. Duban, N. Y., \& Duzgun, M. E. (2013).Views of teachers on the use of drama method in science and technology courses. Turkish Online Journal of Qualitative Inquiry, 4(2).

12. Littledyke, M. (2001). Drama and primary science. Paper presented at the Annual Meeting of the British Educational Research Association, Leeds, England. September 13-15.

13. Iwuala, Z. (2012). Cultural education in the Nigerian languages: The issue of Igbo teaching methodology. Journal of Igbo Language and Linguistics, 5, 85-89.

14. Kauts, A., \& Monika (2013). Effect of dramatization on speaking skills and academic achievement in English among primary students. MIER Journal of Educational Studies, Trends \& Practices, 3(2):163-182.

15. Popoola, A. A. (2014). Effect of play way method on the numeracy skills of early basic education school pupils in Ekiti State Nigeria. Mediterranean Journal of Social Sciences MCSER Publishing, Rome-Italy, 5(10):318-324.

16. Aghajani, H. T. (2011). Role of play in social skills and intelligence of children. Procedia - Social and Behavioral Sciences, 30: 2272 - 2279.

17. Aaron, G. (2014). Folk games and life skills development among children in public schools in the central region of Ghana.Unpublished Thesis of University Of Education, Winneba, Ghana, 195p.

18. Freitas, S. D. (2006). Learning in immersive worlds. Retrieved from http://citeseerxist.psu.edu/viewdoc/download?doi=10.1.1.101.1997\&rep=repl\&type=pdf

19. Cohen, C. (2000). Raise Your Child's Social IQ: Stepping Stones to People Skills for Kids. Silver Springs, MD: Advantage Books.

20. Coie, J. D., Dodge, K. A., and Coppotelli, H. (2001). Dimensions and types of social status: A cross-age perspective. Developmental Psychology, 18, 557-570.

CITATION: Nwachukwu Kingsley Ezechinyere et al (2021). Teaching Methods and Acquisition of Social Skills among Primary Schools Pupils in IkotEkpene Local Government Area. South Asian Res J Human Soc Sci, 3(1): 3-11. 